\title{
O HABEAS DATA BRASILEIRO E SUA LEI REGULAMENTADORA*
}

\author{
José CARLOS Barbosa MoReira**
}

1. Os direitos humanos na Constituição de 1988 - A Constituição brasileira de 5.10.1988 reservou o Título II para o tratamento dos "direitos e garantias fundamentais". No respectivo Capítulo I, cuida-se dos "direitos e deveres individuais e coletivos". Acusa a rubrica duas diferenças interessantes em confronto com as partes correspondentes das anteriores Cartas Políticas: de um lado, junto da alusão a "direitos", aparece a menção a "deveres"; de outro, não se emprega unicamente, como era da nossa tradição, o adjetivo "individuais", acrescentando-se-lhe o "coletivos". Ambas as diferenças revelam certa evolução ideológica (talvez fosse melhor dizer cultural), sobre cujo significado, em nossa opinião profundo, não é este o momento próprio para debruçar-nos.

Importa assinalar por ora que, no Capítulo I, o dispositivo inicial (art. 50) após declarar, no caput, que "todos são iguais perante a lei, sem distinção de qualquer natureza, garantindo-se aos brasileiros e aos estrangeiros residentes no País a inviolabilidade do direito à vida, à liberdade, à igualdade, à segurança e à propriedade" - se desdobra em numerosos incisos, dedicados na maioria à especificação dos direitos assegurados e à indicação dos remédios utilizáveis contra a respectiva violação. Aí se compreendem praticamente todas aquelas prerrogativas a que uma terminologia discutivel do ponto de vista doutrinário, mas já agora (e em definitivo) internacionalmente consagrada, aplica a denominação de "direitos humanos". Assim é que a Constituição alude, por exemplo, à liberdade de manifestação do pensamento (inciso IV), à de consciência e de crença, com o livre exercício dos cultos religiosos (inciso VI), à expressão da atividade intelectual, artística, científica e de comunicação (inciso IX), à inviolabilidade da intimidade, da vida privada, da honra e da imagem das pessoas (inciso $\mathrm{X}$ ), ao sigilo da correspondência e das comunicações telegráficas, de dados e telefônicas (inciso XII), à liberdade de locomoção (inciso XV), de

\footnotetext{
* Trabalho destinado ao volume em homenagem a Héctor Fix-Zamudio, a ser editado pela Corte Interamericana de Direitos Humanos.

** Professor da Faculdade de Direito da Universidade do Estado do Rio de Janeiro, Presidente do Instituto lbero-Americano de Direito Processual.
}

R. Dir. Adm.,

Rio de Janeiro, 211: 47-63,

jan./mar. 1998 
associação para fins lícitos (inciso XVII), ao respeito da integridade física e moral dos presos (inciso XLIX), à necessária observância do devido processo legal (inciso LIV) e assim por diante.

2. Restrições de direito e de fato à proteção dos direitos humanos - Duas observações cabem aqui. A primeira, trivialíssima, é a de que nenhum dos direitos contemplados goza (nem pode gozar) de tutela irrestrita e absoluta. Não se concebe, na vida da sociedade, que direito algum seja compreendido e exercitado como se não existissem outros que, sob tais ou quais circunstâncias, sem determinadas limitações e compressões, inevitavelmente com ele entrariam em choque. A interpretação da Constituição rejeita contradições que nulifiquem qualquer de seus preceitos. Mas, para preservar a todos o espaço devido, é imprescindível levar em conta as interferências que decorrem, para o exercício de cada qual, da necessidade de preservar o dos restantes. $O$ verdadeiro sistema constitucional de proteção de direitos não é aquele que resulta, pura e simplesmente, da leitura isolada de um ou de outro texto: reclama a ponderação atenta dos interesses em jogo e a prudente flexibilização de linhas divisórias, para permitir o convívio tão harmonioso quanto possível de valores igualmente relevantes e ocasionalmente contrastantes. Basta atentar, v.g., nos conflitos que podem surgir, e com freqüência surgem, entre a liberdade de manifestação do pensamento e a obrigatória preservação da intimidade e da honra alheias.

Outra observação, não menos óbvia, diz respeito à distância que lamentavelmente se interpõe entre o conjunto normativo e o quotidiano concreto. Seria ocioso demorar-nos em ilustrar com exemplos o reparo, cujo alcance, de resto, provavelmente transcende quaisquer fronteiras nacionais. É pelo menos extremamente duvidoso que em algum Estado, de ontem ou de hoje, o dia-a-dia da vida social haja refletido ou reflita com inteira fidelidade a imagem desenhada nos textos de Cartas políticas, no que tange - e não só nisso - à reverência para com os direitos humanos. Haverá, é claro, diferenças de grau no descompasso; todavia, será difícil, quiçá impossível, apontar país qualificado, sem nenhuma hipocrisia, para atirar a primeira pedra. A perfeição, bem se sabe, decididamente não é do mundo terreno.

Esta segunda observação comporta um adendo, concernente à origem das violações dos chamados direitos humanos. Ao tratarem do assunto, os meios de comunicação social, e por influência deles muitíssimas pessoas, têm em vista exclusivamente, por assim dizer, os abusos e violências perpetrados pelas polícias e por outras entidades ligadas, direta ou indiretamente, às estruturas oficiais. E uma tendência que predomina até nas manifestações de quase todas as organizações internacionais que se ocupam da matéria. Ela denota uma visão indevidamente restritiva e unilateral do fenômeno. Sem minimizar a importância do aspecto comumente posto em relevo, tudo aconselha a que não se despreze outro: em certas áreas e em certos momentos, a atuação de grupos privados pode assumir gravidade tão grande (ou maior) do que a de aparelhos estatais, como razão de ameaça para a integridade dos mencionados direitos - a começar pelo mais elementar de todos, o direito à vida. Basta pensar na expansão e no fortalecimento da criminalidade organizada, a multiplicar e a alargar, em regiões urbanas e rurais, mormente no terceiro mundo, as "zonas cin- 
zentas",' onde impera sem peias o arbítrio do chefe de quadrilha ou do mais bem armado traficante de drogas, autoinvestido de poderes para determinar o que se pode e o que se não pode fazer no território controlado, ordenar o fechamento de vias públicas e escolas, ocupar a seu talante espaços "estratégicos", reduzir ao silêncio, pela intimidação, os moradores vizinhos e justiçar sumariamente quaisquer suspeitos de desobediência.

3. $O$ direito ao conhecimento e à retificação de dados pessoais - Sob regimes políticos de exceção, e muito especialmente a partir do instante em que se desencadeia o processo de retorno no Estado de direito, costuma aguçar-se a sensibilidade para este ou aquele problema relacionado com a preservação de direitos. Episódios em curso ou já encerrados, mas vivos na memória popular, põem em evidência dificuldades, e carências que até ali talvez não houvessem despertado maior atenção. A humanidade aprende com a história: menos, com certeza, do que seria de desejar̀ - mas aprende...

No Brasil, durante os governos discricionários que se sucederam ao longo de duas décadas, razões bem fundadas fizeram surgir, ou aumentar, uma inquietação relativamente nova, ou quando menos revestida de nova forma. Informaçōes aleatoriamente colhidas, em fontes de discutível idoneidade e por meios escusos, não raro manipuladas sem escrúpulos, ou mesmo fabricadas pela paranóia de órgãos repressivos, viram-se incorporadas a registros oficiais ou paraoficiais e passaram a fornecer critérios de avaliação para a imposição de medidas punitivas ou discriminatórias. Tais critérios eram insuscetíveis de objeção e discussão, até pelo simples e óbvio motivo de que os interessados não tinham acesso aos dados constantes dos registros. Ninguém pode sequer tentar demonstrar a falsidade ou incorreção de algo que ignora em que consiste... Situação desse gênero foi literariamente imortalizada pela pena de Kafka.

O problema tem ligação manifesta com o da preservação do direito à intimidade: ${ }^{2}$ na coleta e armazenamento indiscriminado de dados atinentes a uma pessoa, à revelia dela e sem controle de sua parte, não há como deixar de ver uma invasão da privacidade. A rigor, porém, o que avulta aqui é uma idéia mais particularizada, suscetível de expressão sintética nos seguintes termos: a ninguém se deve negar o conhecimento do que outros sabem ou supõem saber a seu respeito, nem a possibilidade de contestar a exatidão de tais noções e, sendo o caso, retificar o respectivo teor, principalmente quando a utilização dos elementos coligidos seja capaz de causar

1 A expressāo zones grises (ou zones de non-droit) vê-se empregada por autores franceses para designar as áreas em que o ordenamento oficial, sem força para impor-se, é substituído, de facıo, pela "lei da selva”, vide, por exemplo, MINC, Le nouveau moyen áge, Paris, 1993, que alude, v.g., à América do Sul, "dont des régions entières sont souns la domination des rois du pavot, des empereurs de la cocaine et autrs trafiquants" (p. 70).

2 CELSO RIBEIRO BASTOS, in CELSO RIBEIRO BASTOS... IVES GANDRA MARTINS, Comentários à Constituiçāo do Brasil, $2^{2}$ vol. S. Paulo, 1989, p. 361; MANOEL GONÇALVES FERREIRA FILHO, Comentários à Constituiçāo brasileira de 1988, S. Paulo, 1990, p. 82. 
dano material ou moral. ${ }^{3}$ É a essa específica preocupação que corresponde, na Constituição de 1988 , o instituto de que nos vamos ocupar. ${ }^{4}$

4. A garantia processual - O Capítulo "dos direitos e deveres individuais e coletivos" não se limita, em nossa Carta Política, a definir posições jurídicas situadas no plano material: contempla igualmente uma série de remédios processuais cujo emprego se destina a assegurar praticamente, a um tempo, a integridade ou a reintegração dos direitos e o cumprimento dos deveres ou a imposição de sanções a quem os descumpra. Algumas dessas figuras já estavam incorporadas, desde época mais ou menos recente, ao repertório tradicional do ordenamento pátrio. Assim, por exemplo, o habeas corpus - instrumento de proteção contra “ violência ou coação", atual ou iminente, à liberdade de locomoção, isto é, ao direito de ir e vir (art. $5^{\circ}, \mathrm{n}^{\circ}$ LXVIII) - e o mandado de segurança - cabível para proteger "direito líquido e certo" lesado ou ameaçado de lesão por ato ilegal ou abusivo de "autoridade pública ou agente de pessoa jurídica no exercício de atribuições do Poder Público" (art. 5, $\mathrm{n}^{\mathrm{e}}$ LXIX) - são institutos consagrados de longa data em sucessivos textos constitucionais brasileiros.

A esse rol vê-se agora acrescentado o habeas data, por sugestão, ao que consta, ${ }^{5}$ de José Afonso da Silva. Parece dever-se ao ilustre professor da Universidade de S. Paulo não só o acolhimento da matéria no bojo da Constituição, senão também o nomen iuris dado ao remédio processual, com inspiração em terminologia usada na doutrina espanhola, em sentido diverso mas correlato." Eis o teor do dispositivo pertinente (art. 5, $\mathrm{n}^{\mathbf{2}}$ LXXIII): “Conceder-se-á habeas data: a) para assegurar o conhecimento de informações relativas à pessoa do impetrante, constantes de registros ou bancos de dados de entidades governamentais ou de caráter público; $b$ ) para a retificação de dados, quando não se prefira fazê-lo por processo sigiloso, judicial ou administrativo".

3 Expressivamente fala MANOEL GONÇALVES FERREIRA FILHO, ob. cit., p. 81, de "um direito à verdade a respeito de si próprio".

4 Nada do que ficou dito é incompatível com o fato de que também em Estados de instituiçōes democráticas mais longamente consolidadas haja o legislador sentido a conveniência ou a necessidade de regular a matéria. Vide, por exemplo, na Alemanha, a Bundesdatenschutzgesetz (Lei federal sobre proteção de dados), de 27.1.1977; na França, a Lei n 78-17, de 6.1.1978, “relative à l'informatique, aux fichiers et aux libertés"; na Itália, a recente Lei $\mathrm{n}^{2} 675$, de 31.12 .1996 , sobre a "tutela delle persone e di altri soggetti rispetto al trattamento dei dati personali". Cf., em nível constitucional, as disposiçōes do texto espanhol (arts. 18, $n^{2} 4$, e 105, letra $b$ ) e do português (arts. 26, n 2, e 35). Outros dados comparatísticos em ROGÉRIO LAURA TUCCI - JOSÉ ROGÉRIO CRUZ E TUCCI, Constituição de 1988 e processo, S. Paulo, 1989, pp. 175 e ss.; e em OSVALDO ALFREDO GOZAÍNI, Habeas data, in Revista Peruana de Derecho Processal, vol. I, pp. 239 e ss.

5 Há quem aponte antecedentes mais distantes: OTHON SIDOU, Habeas data, mandado de injunção, habeas corpus, mandado de segurança, açāo popular - As garantias ativas dos direitos coletivos, $4^{a}$ ed., Rio de Janeiro, 1992, refere-se à "Proposta de Constituição Democrática para o Brasil", resultante do Congresso Pontes de Miranda, Porto Alegre, 1981, e à Lei estadual n² 842, de 28.12.1984, do Rio de Janeiro.

6 Veja-se o que informa o jurista mesmo, no artigo Habeas data, in O São Paulo de 26.9/2.10.1986, e no Curso de Direito Constitucional positivo, $14^{2} \mathrm{ed}$., S. Paulo, 1997, p. 431. 
Antes de passarmos adiante, cabe assinalar que, ao ver de alguns, não teria sido preciso criar remédio processual novo para tutelar o direito em foco. Consagrado que fosse este em termos substanciais, a respectiva proteção em juízo poderia utilizar, pura e simplesmente, a via já conhecida do mandado de segurança. ${ }^{7}$ A experiência, de certo modo, abona esse pensamento: com efeito, desde a entrada em vigor da Constituição, entendeu-se que era imediatamente aplicável, sem necessidade de aguardar-se regulamentação por lei ordinária, o inciso LXXII do art. $5^{0^{8}} \mathrm{e}$, na falta de disciplina legal específica, utilizaram-sey as normas referentes ao mandado de segurança no processamento e julgamento dos habeas data (por sinal, escassos) impetrados. Seja como for, o fato é que, já completado o nono aniversário da Carta de 1988, produziu o Congresso Nacional a Lei ${ }^{2} 9.507$, de 12.11.1997, que, nos termos da ementa, "regula o direito de acesso a informações e disciplina o rito processual do habeas data" - e na qual, diga-se logo, se vieram a chancelar, consoante se frisará nos momentos oportunos, soluções anteriormente propostas em sede doutrinária e, ao menos em parte, acolhidas pela jurisprudência.

5. Sujeitos passivos - Uma das questões básicas que o legislador teve de enfrentar foi a de saber em face de quem se asseguram o acesso aos dados armazenados e o direito à eventual retificação. Prende-se o problema à expressão "caráter público", empregada na parte final do art. $5^{2}, n^{2}$ LXXII, letra $a$, da Constituição, onde se fala em "registros ou bancos de dados de entidades governamentais ou de caráter público". É fora de dúvida que a cláusula derradeira, sob pena de tornar-se supérflua e redundante, só pode aludir a entidades não governamentais. ${ }^{10}$

Nessa linha, vários autores propuseram para o texto entendimento amplo, que o fizesse abranger, ao lado dos órgãos integrantes das estruturas estatais, essas outras entidades suscetíveis de enquadrar-se na locução final. As fórmulas, compreensivelmente, variaram. Houve quem conceituasse "entidade de caráter público" como "aquela que possui registros de assentamentos pessoais e os fornece a terceiros, isto

7 Assim, v.g., ROGÉRIO LAURA TUCCI - JOSÉ ROGÉRIO CRUZ E TUCCI, ob. cit., pp. 171/2; MANOEL GONÇALVES FERREIRA FILHO, ob. cit., p. 81; JOSÉ CRETELLA JÚNIOR, Comentários à Constituiçäo brasileira de 1988, vol. II, 2a ed., Rio de Janeiro, 1991, pp. 773/4; J. M. OTHON SIDOU, ob. cit., p. 431. No dizer de LUÍS ROBERTO BARROSO, $O$ Direito Constitucional e a efetividade de suas normas, $2^{2}$ ed., Rio de Janeiro, 1993, p. 217, a valia do remédio " $\varepsilon$, no fundo, essencialmente simbolica".

8 V.g. CELSO RIBEIRO BASTOS, ob. vol. cit., pp. 365/6, com apoio em parecer normativo do entāo Consultor-Geral da República SAULO RAMOS, in Diário Oficial, Seçāo I, de 11.10.1988, pp. 19.804 e ss. especialmente 19.810/12; JOSÉ CRETELLA JÚNIOR, ob. e vol. cit., p. 770; JOSÉ DA SILVA PACHECO, O mandado de segurança e outras açōes constitucionais típicas, $2^{2}$ ed., S. Paulo, 1991, pp. 279/80.

9 Conforme sugerira, de resto, o próprio JOSÉ AFONSO DA SILVA, no art. cit. em a nota 6.

10 Com razão CALMON DE PASSOS, Mandado de seguraņa coletivo - Mandado de injunçāo Habeas dara, Rio de Janeiro, 1989, pp. 140/1; OTHON SIDOU, ob. cit., p. 437; JOSÉ AFONSO DA SILVA, Curso cit., p. 453. Inaceitável a opinião que pretendeu excluir da área de proteção do habeas-data, pura e simplesmente, as entidades privadas: assim VICENTE GRECO FILHO, Tutela constitucional das liberdades, S. Paulo, 1989, p. 177. 
é, não os detêm para seu uso exclusivo, com vistas a definir suas opções e tomar decisōes" "; quem se referisse às "pessoas privadas que prestem serviços públicos ou de utilidade pública, ou prestem serviços ao público" '2; quem, de maneira mais sintética, fizesse residir a marca do "caráter público" na mera circunstância de poder a entidade, "através de registros públicos ou banco de dados, fornecer informações sobre a pessoa"..$^{13}$

O legislador, com acerto, deixou-se guiar por semelhante orientação. Nos termos do parágrafo único do art. 12, “considera-se de caráter público todo registro ou banco de dados contendo informações que sejam ou possam ser transmitidas a terceiros ou que não sejam de uso privativo do órgão ou entidade produtora ou depositária das informações". A idéia essencial, como se vê, é a da comunicabilidade a terceiros: se a entidade se cinge a coligir e armazenar os dados para seu próprio e exclusivo uso, não infringirá a Constituição caso negue à pessoa de quem se trata o acesso ao conteúdo dos registros ou bancos. Note-se, porém, que a lei não reclama a transmissão atual: contenta-se com a possibilidade dela. Isso reduz consideravelmente a área excluída da proteção, na qual só acharão espaço as situações em que fique clara a impossibilidade da comunicação a terceiros pela entidade depositária das informações.

Exemplos típicos de entidades "de caráter público" são os serviços de proteção ao crédito, cujos registros naturalmente se destinam à orientação dos respectivos usuários. Já assim se ensinava antes mesmo do advento da Lei $\mathrm{n}^{2} 9.507 .14$

6. O pré-requisito da tentativa extrajudicial - Outra questão relevante consiste em saber se deve ou não exigir-se, como pressuposto de admissibilidade da ação de habeas data, que aquele que pretende inteirar-se do conteúdo do registro ou banco de dados se dirija, antes de mais nada, à própria entidade que o mantém. Afirmativa que seja a resposta, parece lógico que unicamente se abra a via judicial na hipótese de recusa ao acesso ou à retificação cabivel.

O ponto foi objeto de controvérsia no período anterior à Lei n 9.507. Parte da doutrina considerou dispensável a provocação prévia da entidade supostamente depositária da informação ${ }^{15}$. A jurisprudência, entretanto, inclinou-se para a tese

11 CALMON DE PASSOS, ob. cit., p. 141.

12 LUÍS ROBERTO BARROSO, ob. cit., p. 218.

13 ERNANE FIDÉliS DOS SANTOS, Manual de Direiro Processual Civil, vol. 3, $4^{2}$ ed., S. Paulo, 1996, p. 208.

14 V.g. JOSÉ CRETELLA JÚNIOR, ob. e vol. cit., p. 774; CALMON DE PASSOS, ob. cit., p. 141; LUIS ROBERTO BARROSO, ob. cit., p. 218; JOSÉ AFONSO DA SILVA, Curso cit., p. 433; DIOMAR ACKEL FILHO, Writs constitucionais, S. Paulo, 1988, p. 124

is Nesse sentido, CELSO RIBEIRO BASTOS, ob. e vol. cit., p. 365; enfaticamente, OTHON SIDOU, ob. cit., pp. 440/2 (admitindo embora que a lei regulamentadora viesse a formular a exigência - o que em todo caso, ao ver do autor, desvirtuaria o instituto "enquanto garantia constitucional célere"). Aliter CÉLIO BORJA, $O$ mandado de injunção e o habeas data, in Revista Forense, vol. 306, p. 47, o qual, todavia, se contentava com a "negativa (...) tácita do fornecimento da informação" - e, ajunte-se, levava em conta exclusivamente o caso de registros ou bancos de dados mantidos pela Administraçāo Pública. Igual limitação, compreende-se (vide, supra, a nota 9) em VICENTE GRECO FILHO, ob. cit., p. 177, que porém chegava à conclusão oposta. "A impetração não depende de prévio pedido administrativo". 
contrária. ${ }^{16}$ Não configurada a resistência da entidade, faltaria ao impetrante interesse processual.

Optou o legislador pela solução restritiva. Com efeito: antes de disciplinar o processo do habeas data, cuida a Lei $n^{2} 9.507$, nos arts. $2^{2}$ a $4^{2}$, do requerimento a ser feito pelo interessado "ao órgão ou entidade depositária do registro ou banco de dados"; e, ao tratar da petição inicial da ação, no art. $8^{2}$, preceitua que ela seja instruída com prova da recusa em atender a tal requerimento, sob pena de - com a ressalva que adiante se fará (infra, $\mathrm{n}^{2} 10$ ) - indeferi-la o juiz in limine (art. 10, caput). É certo que não se exige manifestação expressa do órgão ou entidade: basta ao impetrante provar que se escoou o prazo legal sem decisão sobre o requerimento, o que caracterizará recusa tácita.

7. Procedimento da tentativa extrajudicial - Convém descrever sumariamente o procedimento dessa medida extrajudicial arvorada pelo legislador em pré-requisito da admissibilidade da ação de habeas data. De acordo com o art. $2^{2}$ e seu parágrafo único da Lei n 9.507, uma vez apresentado o requerimento, deve o órgão ou entidade destinatária deferi-lo ou indeferi-lo no prazo de 48 horas e comunicar a decisão ao requerente em 24 horas (nas 24 horas subseqüentes, entende-se). $O$ contexto mostra que, em princípio, o escopo desse requerimento é o acesso do interessado ao conteúdo do registro ou banco de dados. Bem se compreende, aliás, que normalmente não possa ele, até então, requerer outra coisa, por ignorar o que consta ali. Se, contudo, em hipótese especial, o interessado já tiver ciência daquele conteúdo (por exemplo, mediante certidão que lhe haja sido expedida pela repartição administrativa), afigura-se evidente a possibilidade, que desde logo se the abre, de requerer diretamente a retificação a seu ver cabível.

No comum dos casos, repita-se, pedirá o requerente que se lhe exibam os elementos constantes do registro ou do banco de dados. É para a decisão sobre esse pedido que o art. $2^{2}$, fine, marca o prazo de 48 horas. Não diz a lei, porém, que consequiência acarreta a inobservância de tal prazo, nem a do prazo de 24 horas fixado para a comunicação da decisão ao requerente. Note-se que para caracterizar a recusa tácita, e por conseguinte abrir a via judicial ao interessado, é mister que decorram "mais de dez dias sem decisão" (art. 8, parágrafo único, n² 1). 0 art. $6^{2}$ do texto aprovado pelo Congresso Nacional cominava multa para "o descumprimento do disposto nos artigos anteriores", entre os quais certamente se incluía o art. $2^{2}$, mas semelhante dispositivo veio a ser vetado pelo Presidente da República. ${ }^{17}$

16 Assim, v.g., o extinto Tribunal; Federal de Recursos, 16.3.1989, H.D. n 7, in Diário da Justiça de 15.5.1989; o Tribunal Regional Federal da 5a Regiāo, 6.10.1994, A.C. $n^{\circ} 94.05 .57164$, in A Constituição na visão dos tribunais, vol. 1, S. Paulo, 1997, p. 168; o Superior Tribunal de Justiça, Súmula da Jurisprudência Predominante, $\mathrm{n}^{2} 2$. Em igual sentido já decidiu o Supremo Tribunal Federal, em 19.9.1991, Rec. De H.D. № 22, in Diário da Justiça de 1².9.1995, p. 27.378. Preconizava essa orientação, em sede doutrinária, JOSÉ CRETELLA JÚNIOR, ob. e vol. cit., pp. 772/3, o qual formulava o voto (alendido) de que viesse a esposá-la a "futura norma regulamentadora".

17 Vide o Diário Oficial, Seção I, de 13.11.1997, p. 26.158. 
Deferido o requerimento de acesso ao registro ou banco de dados, o depositário "marcará dia e hora para que o requerente tome conhecimento das informações" (art. 3, caput). Então, uma de duas: ou estas se afiguram exatas, ou não. No primeiro caso, tollitur quaestio, no segundo, "o interessado, em petição acompanhada de documentos comprobatórios, poderá requerer sua retificação" (art. $4^{\mathfrak{Q}}$, caput). Fazendo-a, no decêndio seguinte à entrega do requerimento, a entidade ou órgão disso dará ciência ao interessado (art. $4^{\stackrel{Q}{ }}, \S 1^{\stackrel{Q}{ })}$. Concebe-se que este, embora não descubra propriamente inexatidão, queira fazer constar do registro ou do banco de dados "explicação ou contestação" a respeito, "justificando possível pendência sobre o fato objeto do dado". Em tal hipótese, a explicação "será anotada no cadastro do interessado" (art. $4^{2}, \S 2^{2}$ ).

A recusa da entidade ou órgão depositário, em qualquer caso - indeferindo o requerimento de acesso ao registro ou banco de dados, ou rejeitando o pedido de retificação, ou ainda negando-se a inserir a "explicação ou contestação" — justifica o exercício, pelo interessado, da ação de habeas data.

8. A ação de habeas data - De tal remédio judicial tratam os arts. $7^{\circ}$ e ss. da Lei n9.507. O primeiro dispositivo enumera, em três incisos, os casos de cabimento, correspondentes às três hipóteses de recusa, acima discrimịnadas, da entidade ou órgão depositário. Pode exercitar-se a ação de habeas data com o fito de compelir o impetrado a dar conhecimento ao impetrante de informações a este relativos (inciso I), a retificar os dados inexatos (inciso II) ou a fazer a anotação pleiteada nos respectivos assentamentos (inciso III).

Esse texto conjuga-se com o do art. $8^{\circ}$, parágrafo único, também desdobrado em três incisos, que impõem ao impetrante instruir a petição inicial com a prova da recusa expressa ou tácita da entidade ou órgão a atender ao requerimento de acesso (inciso I), ou de retificação (inciso II), ou de anotação (inciso III). Caracteriza recusa tácita o decurso, sem decisão, de "mais de dez dias" no primeiro caso, e de "mais de quinze dias", nos outros dois.

Observe-se que a Lei $\mathrm{n}^{2} 9.507$ ampliou em certa medida o âmbito do remédio previsto no art. 50, $n^{2}$ LXXII, da Constituição da República. Só se refere esse dispositivo ao "conhecimento de informações" (letra $a$ ) e à "retificação de dados" (letra $b$ ). O legislador ordinário aditou uma terceira possibilidade: a da anotação, nos assentamentos da entidade ou órgão, da "contestação ou explicação" do interessado. Por via indireta, alargou a franquia constitucionalmente deferida: não se reconhece apenas um direito ao conhecimento de dados ou à retificação dos inexatos, mas também à anotação de contestações ou explicações. Sublinhe-se que anotar contestação ou explicação não é o mesmo que retificar dado constante do banco ou registro: na retificação, modifica-se (ou, eventualmente, cancela-se) ${ }^{18}$ algo; na anotação, acrescenta-se algo ao que consta do banco ou registro.

18 CELSO RIBEIRO BASTOS, ob. e vol. cit., p. 364, já sustentava, à vista do texto constitucional, que a locução "retificação de dados" devia "ser entendida amplamente para incluir a própria supressāo quando se tratar de informaçōes pertinentes à vida íntima da pessoa". 
A ampliação não merece censura do ponto de vista constitucional: o que a lei ordinária não poderia fazer é estreitar, diminuir, restringir o campo de atuação do habeas data, delimitado na Carta Política. De resto, apesar da diferença ontológica, se o remédio se presta à consecução de providência mais intensa (retificação de dados), é razoável admitir, a fortiori, que se preste à de providência menos intensa (simples anotação de explicações fornecidas pelo requerente, sem alteração dos assentamentos existentes).

9. Legitimação ativa para a causa - Importa precisar quem se habilita a pleitear o conhecimento e, eventualmente, a retificação (ou complementação) dos dados constantes de registros ou bancos. É o problema que, na linguagem científica do processo, se designa pela expressão "legitimação ativa para a causa".

$O$ art. $5^{\circ}$ do texto constitucional ministra um primeiro dado relevante, quando, na letra a do inciso LXXII, alude a "informaçōes relativas à pessoa do impetrante". Daí se tira imediatamente que não é lícito a quem quer que seja utilizar o habeas data para obter informações (menos ainda para tentar retificá-las) que, digam respeito a outrem. ${ }^{19}$ Entretanto, não se há de interpretar a palavra "pessoa" como adstrita a indicar características somáticas ou psíquicas, físicas ou espirituais do interessado: pode tratar-se igualmente de sua situação patrimonial, de sua condição jurídica, de sua participação em sociedades ou associaçōes, de sua filiação (atual ou pretérita) a entidades políticas, a clubes, a agremiações de qualquer natureza, e assim por diante. ${ }^{20}$ Em suma: não se compreende apenas aquilo que distingue o impetrante, em sua singularidade ontológica, de todos os outros indivíduos da espécie, mas também os mais variados aspectos de sua vida de relação na sociedade.

Nada importa que se cogite de pessoa física ou jurídica: ${ }^{21}$ o texto constitucional

19 Afirma JOSÉ AFONSO DA SILVA. Curso cit., p. 432, que "o direito de conhecer e retificar os dados, assim como o de interpor o habeas data para fazer valer esse direito quando não expontaneamente prestado, é personalíssimo do titular dos dados" (grifos do autor). Em igual sentido: ROGÉRIO LAURIA TUCCI - JOSÉ ROGÉRIO CRUZ E TUCCI, ob. cit., p. 180; CALMON DE PASSOS, ob. cit., pp. 144/5 (onde se repele até, expressamente, a possibilidade da substituição processual do interessado por sindicato ou entidade de classe, bem como a sucessão na pendência do feito); ERNANE FIDÉLIS DOS SANTOS, ob. e vol. cit., p. 208; VICENTE GRECO FILHO, ob. cit., p. 176; DIOMAR ACKEL FILHO, ob. cit., p. 121 (o qual, todavia, abre exceção para o herdeiro legítimo e o cônjuge supérstite no que tange a dados concernentes à pessoa falecida); menos categórico, LUfS ROBERTO BARROSO, ob. cit., p. 218. Mais flexível que a predominante é a posição de OTHON SIDOU, ob. cit., p. 436, para quem as informaçōes pretendidas não se restringem necessariamente "ao indivíduo uti singuli", senão que podem abranger, "as demais pessoas sob sua dependência familiar"; registre-se, aliás, que também JOSÉ AFON. SO DA SILVA, ob. cit., p. 282, inclui entre as informações pessoais "as dos familiares". Vide, na jurisprudência recusando legitimidade a sindicatos, TRF - $1^{2} \mathrm{R}$., 3.9.1990, RHD ne 0117170 , in D.J. de 24.9.1990, p. 22.052, e TRF - $4^{2} \mathrm{R}, 28.6 .1991$, AHD $n^{2} 0409595$, in D.J. de 21.8.1991, p. 19.494; afirmando o caráter personalíssimo da garantia e excluindo a possibilidade de seu exercício por substituto processual ou por ação coletiva, TRF - 4 R., 15.8.1991, HD ne 0409112, in D.J. de 11.9.1991, p. 21.820; negando a legitimaçāo de parente de pessoa desaparecida, TRF - $1^{2}$ R., 25.10.1994, Apel. em MS $n^{2}$ 0102148 , in D.J. de 24.11.1994, p. 67.984.

20 Mais restritiva a opiniāo de JOSÉ DA SILVA PACHECO, ob. cit., p. 278.

21 Contra a segunda possibilidade, sem fundamentação convincente: CELSO RIBEIRO BASTOS, ob. e 
não distingue; e com referência ao mandado de segurança foi sempre esse o entendimento dominante. Ademais, não obstante a letra à primeira vista limitativa do art. $5^{\circ}$, caput (verbis "aos brasileiros e aos estrangeiros residentes no País"), a melhor interpretação ao nosso ver, é a que estende a franquia inclusive aos estrangeiros não residentes. Já sob regimes constitucionais anteriores, negava a doutrina mais autorizada que ficassem tais estrangeiros totalmente a descoberto da proteção assegurada por esse tipo de garantias; ${ }^{22}$ e não é outro, hoje, o ensinamento mais prestigioso. ${ }^{23}$

10. As espécies de pedido e a estrutura do processo - Consoante se explicou (supra $\mathrm{n}^{2} 7$ ), ao dispor sobre o procedimento prévio perante a entidade ou órgão depositário das informações, contemplou a Lei $n^{2} 9.507$, em termos expressos, a possibilidade do respectivo desdobramento em duas fases; uma destinada a dar a conhecer ao requerente o teor dos dados constantes do registro ou banco (art. 3); outra, eventual, em que se tratará da retificação dos dados porventura inexatos, ou da anotação de "explicação ou contestação" fornecida pelo interessado (art. 4, caput e $\S 2^{2}$ ). Ressalvou-se, então, a hipótese de já ter o requerente ciência do teor dos assentamentos, e por isso interessar-lhe exclusivamente a retificação e/ou a anotação - caso em que, como é intuitivo, nada mais precisará requerer que uma dessas últimas providências, ou ambas.

$\mathrm{Na}$ disciplina do processo judicial, não se enxerga a previsão de desdobramento análogo. $\mathrm{O}$ art. 13, atinente à sentença que julga procedente o pedido, cuida em separado de duas hipóteses, ordenando ao juiz marcar dia e hora para que o impetrado "apresente ao impetrante as informações a seu respeito" (inciso I) ou (atente-se na conjunção alternativa) "apresente em juízo a prova da retificação ou da anotação feita nos assentamentos do impetrante" (inciso II; melhor seria dizer: "nos assentamentos relativos ao impetrante"). O legislador, tem-se a impressão, pressupôs que a este por força interessará, alternativamente, uma de duas providências: o acesso aos dados ou então a retificação ou anotação.

Quid iuris, no entanto, se o interessado, ignorante do teor dos assentamentos, quiser tomar ciência deles e mais, sendo o caso, promover-lhes a retificação (ou, ajunte-se, fazer inserir sua "explicação ou contestação")? Antes da Lei ne 9.507, sustentava doutrina autorizada ${ }^{24}$ que um único e mesmo processo bastaria para perseguir ambas as finalidades. Do ponto de vista procedimental, dois caminhos seriam viáveis: ou (a) impor-se ao impetrante pleitear, $a b$ initio e desde logo, o acesso aos dados e, se inexatos ou incompletos, a retificação ou anotação cabível; ou então (b) abrir-se-lhe, após a exibição dos assentamentos, nova oportunidade

vol. cit., p. 363. Corretamente, HELY LOPES MEIRELLES, Mandado de segurança - Af̧ão popular - Ação civil pública - Mandado de injunção - Habeas data, $17^{\mathrm{a}}$ ed., atualizada por ARNOLDO WALD, S. Paulo, 1996, p. 186; na jurisprudência, TRF $-2^{2}$ R. 8.11.1995, Apel Civ. $\mathrm{n}^{2}$ 0218225, in D.J. de 30.1.1996, p. 3.224 .

22 V.g. PONTES DE MIRANDA, Comentários à Constituição de 1967, t. IV, S. Paulo, 1967, p. 700.

23 Assim: PINTO FERREIRA, Comentários à Constituição brasileira, $1^{\circledR}$ vol. S. Paulo, 1989, p. 59, CELSO RIBEIRO BASTOS, ob. e vol. cit., p. 4.

24 Vide, por todos, JOSÉ AFONSO DA SILVA, Curso cit., pp. 432/3. 
para, querendo, pedir a retificação ou anotação. A preferência pelo segundo caminho implicaria desdobramento do processo judicial em duas fases, à semelhança do previsto nos arts. $3^{e}$ e $4^{e}$ do diploma regulamentador, quanto ao procedimento da tentativa prévia de solução extrajudicial.

O assunto não recebeu do legislador ordinário a devida atenção. Suponhamos que o juiz, dando pela procedência do pedido de acesso aos dados, marque dia e hora para a respectiva apresentação e, cumprida a ordem, venha o impetrante a verificar a existência de inexatidões até ali ignoradas. Não esclarece a lei como se há de acudir a tal emergência. Seria manifesto despropósito atribuir ao interessado o ônus de impetrar novo habeas data, para pedir, dessa vez, a retificação e/ou a anotação. Por outro lado, nem sempre lhe será fácil, ou sequer possível, demandar desde o começo a exibição e a retificação ou anotação: o conhecimento do teor dos dados, em regra, constituirá pressuposto necessário do interesse na alteração ou no aditamento (supra, $\mathrm{n}^{2} 7$ ). Nada no texto legal autoriza a ilação de que o impetrante precise, na inicial, cumular os pedidos: ele fica livre, sem dúvida, de cumulá-los, se quiser e puder; é o máximo que cabe dizer.

Subsiste, pois, o problema: como proceder, na hipótese de, julgado procedente o pedido de acesso aos dados, e exibidos estes, parecer ao impetrante necessário que se retifiquem, ou que se insira nos assentamentos "explicação ou contestação"? Não vemos outra saída senão o prosseguimento do processo, para esse outro fim, com repetição das providências destinadas a assegurar o contraditório sobre o novo thema decidendum (art. 99; vide, infra, o $\mathrm{n}^{2} 11$ ). Há desvantagens 6 bvias, entre elas a de gerar a possibilidade de duas sentenças, à feição do que ocorre no processo da ação de prestação de contas ex art. 915 do Código de Processo Civil; mas não nos ocorre alternativa melhor. ${ }^{25}$

25 Em trabalho anterior a Lei n 9.507, escrevia CALMON DE PASSOS, ob. cit., p. 153: “(...) no particular do habeas data para retificação, a única peculiaridade que vislumbramos é a da possibilidade de seu ajuizamento conexo ao habeas data impetrado para obter as informaçōes. Segundo já esclarecido, prestadas as informaçōes pelo impetrado, pode o impetrante discordar delas, pedindo sua retificaçāo (aditamento, eliminaçāo, correção do que nelas consta etc.), e isso em verdade nāo é mais do que o habeas data da alínea $b$, embutido no processo relativo à hipotese da alínea $a$, possível pela conexão, que reclama simultâneo processamento e julgamento, dado o reflexo do habeas data retificador sobre o conteúdo da decisão no habeas data ajuizado para obter as informaçōes" (grifos do original). O primeiro periodo transcrito sugere a idéia de cumulação originária dos pedidos - em nossa opiniāo, como ficou dito no texto, visível, mas pouco provável. Quanto à eventualidade da discordância do impetrante com o teor dos assentamentos exibidos, parece difícil, para dizer o menos, o cogitado "simultâneo processamento e julgamento". Com efeito: a discussão acerca da retificação - e, a fortiori, a respectiva decisāo pressupōem já decidido favoravelmente ao impetrante o pedido de informações (o único até então formulado, ao que tudo faz crer), e até ja " prestadas" aquelas, conforme assinala o próprio autor. Tampouco soa compreensível a alusão ao "reflexo do habeas data retificador sobre o conteúdo da decisão no habeas data ajuizado para obter as informaçōes". O contrário é que se nos afigura verdadeiro: cabe 2 decisāo sobre o pedido de informaçōes a prioridade lógica sobre a outra, antes de mais nada se decide se o impetrante tem o direito de acesso aos dados, depois se examinam as possíveis objeçōes à respectiva respectiva exatidão. Acrescente-se que a segunda decisāo não fica condicionada à primeira em seu comeina, señ̄o em sua existência mesma rejeitado o pedido de informaçōes, nem sequer se vai adiante; acolhido, passa-se ao resto, sem que fique em absoluto predeterminado o sentido em que se julgará a 
11. Procedimento - O procedimento estabelecido pelos arts. $8^{2}$ e ss. da Lei $n^{2}$ 9.507 segue, em linhas gerais, o padrão do mandado de segurança, tal como configurado na Lei $n^{2} 1.533$, de 31.12.1951. Somando-se à patente afinidade entre os dois institutos, isso autoriza a fácil inferência de que, em princípio, as lacunas do novo diploma legal devem ser complanadas mediante aplicação analógica das disposições do anterior. Naturalmente, não se exclui - do mesmo modo que no mandado de segurança - a aplicabilidade subsidiária das regras comuns, contidas no Código de Processo Civil, em tudo que não tiver disciplina específica na Lei $\mathrm{n}^{2} \mathbf{9 . 5 0 7}$ e for compatível com sua sistemática.

Da escolha do modelo decorre a simplicidade e (espera-se) a celeridade do rito. A petição inicial, que preencherá os requisitos habituais (arts 282 e 283 do Código de Processo Civil), será apresentada em duas vias, e os documentos que instruírem a primeira serão reproduzidos por cópia junta à segunda (art. $8^{2}$, caput). Entre os documentos indispensáveis, como já se disse (supra, $\mathrm{n}^{0} 6$ ), figura - conforme a hipótese - a prova da recusa expressa do impetrado ao acesso às informações, à retificação, à anotação, ou a prova do decurso in albis do prazo legalmente marcado (recusa tácita) (art. 8², incisos I a III).

Sujeita-se a petição inicial, como a de qualquer ação, ao controle liminar do juiz, que a indeferirá "quando não for o caso de habeas data, ou se lhe faltar algum dos requisitos previstos" (art. 10, caput). Não deve o órgão judicial, entretanto, indeferir a inicial sem antes conceder ao impetrante o prazo de dez dias, para suprir deficiências ou corrigir outros defeitos sanáveis (Código de Processo Civil, art. 284). Nos termos do art. 10, caput, "do despacho de indeferimento caberá recurso previsto no art. 15" (a publicação oficial omitiu, à evidência, o artigo "o" antes de "recurso"). Infeliz a redação: chama "despacho" a ato que, podo fim ao processo no nascedouro, a observar-se a terminologia do Código (art. 162, $\S 1^{9}$ ) sem dúvida constitui "sentença", tanto quanto a decisão concessiva ou denegatória do habeas data, de que fala o art. 15.

Deferida que seja a petição, $a b$ initio ou após a emenda ou complementação tempestiva, "o juiz ordenará que se notifique o coator do conteúdo da petição, entregando-lhe a segunda via apresentada pelo impetrante, com as cópias dos documentos, a fim de que, no prazo de dez dias, preste as informações que julgar necessárias" (art. 99). "Feita a notificação, o serventuário em cujo cartório corra o feito juntará aos autos cópia autêntica do ofício endereçado ao coator, bem como a prova da sua entrega a este ou da recusa, seja de recebê-lo, seja de dar recibo" (art. 11). Ao cabo do decêndio fixado no art. $9^{\circ}$, haja sido apresentada ou não a resposta (que a lei denomina "informações"), encaminham-se os autos ao Ministério Público, para que emita parecer em 5 dias, e em seguida ao juiz, para que decida também num qüinquíídio (art. 12).

pretensão à retificação (o impretante pode ter razão em querer conhecer os dados e não a ter em querer retificá-los). A questão primeiramente decidida caracteriza-se como preliminar, não como prejudicial, da outra (sobre a distinção entre os conceitos, vide BARBOSA MOREIRA, Comentários ao Código de Processo Civil, vol. V, $6^{\mathrm{a}}$ ed., Rio de Janeiro, 1993, pp. 599/600). 
12. Sentença - A sentença, concessiva ou denegatória do habeas data em primeiro grau de jurisdição, é impugnável por apelação (art. 15, caput, aliás supérfluo: no silêncio da lei, incidirá de qualquer jeito o art. 513 do Código de Processo Civil). Há uma pecualiaridade: no caso de acolhimento do pedido, o recurso é desprovido de efeito suspensivo - ou; consoante preferiu dizer o legislador, "terá efeito meramente devolutivo" (art. 15, parágrafo único). Significa isso que o impetrado deve cumprir a sentença incontinenti, tão logo lhe seja comunicado o respectivo teor, "por correio [passe o cacófato!], com aviso de recebimento, ou por telegrama, radiograma ou telefonema, conforme o impetrante o requerer" (art. 14, caput, exigido o reconhecimento da firma do juiz nos originais apresentados à agência expedidora, no caso de transmissão telegráfica, radiofônica ou telefônica (art. 14, parágrafo único).

Diversamente do que se dá com o mandado de segurança, ex vi do art. 12, parágrafo único, da Lei ${ }^{2} 1.533$, não existe, para o habeas data, determinação legal de que sentença concessiva da medida fique obrigatoriamente sujeita à revisão em segundo grau de jurisdição; mas, se o impetrado vencido for órgão da União, do Estado ou do Município, será de rigor o reexame, por aplicação subsidiária da regra do art. 475, n² II, do Código de Processo Civil.

Isso não obsta, convém ressaltar, a que o órgão tenha de cumprir desde logo a sentença. Parece impróprio falar em "execução", no sentido técnico: não há, a rigor, condenação cujo descumprimento dê ensejo à instauração de processo executivo. Julgado procedente o pedido, o órgão judicial emite uma ordem dirigida ao coator, para que, no dia e hora fixados, apresente as informações requeridas ou a prova da retificação ou anotação (art. 13; cif., supra, o n⿳9 9). Â luz da classificação adotada por parte expressiva da doutrina brasileira, estamos aqui diante de sentença tipicamente mandamental. ${ }^{26} \mathrm{~A}$ omissão voluntária e injustificada em cumprir a ordem pode configurar crime de desobediência por parte do agente responsável (Código Penal, art. 330). Não fica afastada a imposição de multa diária ao impetrado, com base no art. 461, § 4, do Código de Processo Civil: induvidosa, ao nosso ver, a analogia, pois aqui também se cogita de ação cujo objeto é o cumprimento de obrigação (lato sensu) de fazer.

13. Suspensão provisória do cumprimento da ordem - No tocante ao mandado de segurança, inovação introduzida pela Lei $n^{2} 4.348$, de 26.6 .1964 , abriu à pessoa jurídica de direito público interessada a faculdade de requerer ao presidente do tribunal competente para julgar o recurso a suspensão provisória da "execução" da

26 Cf. JOSE DA SILVA PACHECO, ob. cit., p. 273. VICENTE GRECO FLHO, ob. cit., p. 175, distingue a ação de habeas data - e, por conseguinte, entende-se, a sentença de procedência - seria mandamental na hipótese da letra $a$ do dispositivo constitucional (direito ao conhecimento dos dados), mas constitutiva na da letra $b$ (direito à retificação), porque neste segundo caso se pleitea "a modificação do mundo jurídico". O argumento seria convincente se a sentença concessiva, por virtude própria, lograsse concretizar a modificação, pô-la em ato, como fazem as verdadeiras sentenças constitutivas (de anulaçăo de casamento ou testamento, de divórcio etc.). Aqui, é outra coisa que sucede: tal qual na hipótese da letra $a, 0$ juiz (recitus: a sentença) nāo modifica por si assentamento algum: ordena, isso sim, que o impetrado proceda à modificaçāo. 
ordem favorável ao impetrante, por hipótese concedida quer in limine litis, quer na sentença. Talvez haja, com efeito, ponderáveis razões de interesse público a desaconselhar o cumprimento imediato, visto como causador de dano irreparável ou de difícil reparação, a mostrar-se afinal injusto se porventura provido o recurso e denegada a segurança na instância superior. Tomou-se a louvável cautela de restringir expressamente a possibilidade da suspensão aos casos em que necessária para "evitar grave lesão à ordem, à saúde, à segurança e à economia públicas". Tal disposição seria reproduzida, no que tange à concessão in limine litis, na disciplina da chamada ação civil pública, exercitável para promover a responsabilidade por danos ao meio ambiente, ao consumidor, a bens e direitos de valor artístico, estético, histórico, turístico e paisagístico, a qualquer outro interesse difuso ou coletivo, e ainda por infração da ordem econômica (Lei no 7.347, de 24.7.1985, art. $1^{2}$ ). O requisito da "grave lesão à ordem, à saúde, à segurança e à economia públicas" aparece igualmente no art. $4^{\circ}$, caput, da Lei $n^{2} 8.437$, de 30.6.1992, o qual dispõe sobre a suspensão de liminares concedidas contra atos do Poder Público ou seus agentes; aí se acrescenta a exigência de ser o caso "de manifesto interesse público ou de flagrante ilegitimidade".

Afigurou-se ao legislador que emergências do mesmo tipo seriam concebíveis no habeas data. E realmente se imagina com facilidade que a infundada concessão da medida por erro do juiz venha a ser cassada em grau de recurso, sem que se torne possivel, a essa altura, restaurar o primitivo estado de coisas. Uma retificação de assentamentos é, em princípio, suscetível de ser desfeita, mas não haverá como desfazer a revelação ao impetrante de dado constante de registro ou banco: aí, quod factum est infieri nequit. Compreende-se, por conseguinte, que também a Lei $\mathrm{n}^{\mathrm{Q}}$ 9.507 haja tratado de consagrar, no art. 16, mecanismo semelhante ao descrito acima.

Ao fazê-lo, porém, desprezou o cuidado de indicar as hipóteses que legitimam a suspensão, afastando-se do modelo inspirador. Lido à pressa, o art. 16 da Lei $n^{2}$ 9.507 sugere que se pode requerer a providência em qualquer caso, exista ou não exista relevante interesse público em jogo. $\mathrm{E}$, ao contrário dos outros diplomas mencionados, nem sequer se impõe ao presidente do tribunal que fundamente a decisão suspensiva. É verdade que, a partir da entrada em vigor da Carta de 1988, preceitos desse gênero se tornaram supérfluos: a exigência da fundamentação está hoje posta em nível constitucional (art. $93, \mathrm{n}^{\mathbb{Q}}$ IX) e prevalece mesmo no silêncio da lei ordinária. Contudo, a presença da cláusula nos textos mencionados acima tema a utilidade prática de pôr em relevo que o requerimento de suspensão só pode ser deferido com base na efetiva ocorrência, inequivocamente comprovada e demonstrada na motivação de sentença, de uma ou mais de uma daquelas situações previstas (perigo de grave lesão à ordem pública, ou à saúde pública etc.).

Não soa razoável que se tenha querido deixar a suspensão da ordem à inteira discrição do presidente do tribunal. Pensamos que também no particular há lacuna da Lei $n^{2} 9.507$, a ser complanada mediante a aplicação das disposiçōes análogas correspondentes. ${ }^{27}$ Impede ajuntar que a decisão do presidente do tribunal comporta impugnação por meio de agravo para o próprio tribunal (art. 16, fine).

27 Há precedente judicial: o TRF-4a R., em 22.9.1993, Agr. Reg. na Susp. de Seg. ne 0430502, in D.J. 17.11.1993., p. 49.087, entendeu aplicável ao habeas data a norma do art. $4^{2}$ da Lei $n^{0} 8.437$. 
14. Coisa julgada - De acordo com o art. 18 da Lei $n^{0} 9.507$, "o pedido de habeas data poderá ser renovado a se a decisão denegatória não lhe houver apreciado o mérito". Aqui se depara, igualmente, disposição mutuada da Lei n² 1.533 (art. 16), relativa ao mandado de segurança. A esse respeito, superadas incertezas iniciais, a jurisprudência do Supremo Tribunal Federal veio a firmar-se no sentido de que, se denegada a segurança por entender-se inexistente o direito alegado pelo impetrante, a decisão é suscetível de produzir coisa julgada material, a impedir qualquer nova apreciação judicial da lide. ${ }^{28}$

É o entendimento que sem dúvida prevalecerá quanto ao habeas data. Suponhamos, por exemplo, que alguém pleiteie, por essa via, a retificação de dado constante de registro ou banco, mas o juiz, examinando a matéria, não descubra a suposta inexatidão. A sentença denegará a ordem, declarando que o assentamento é exato e, portanto, o impetrante não tem o direito de vê-lo modificado. Inexiste motivo para recusar a tal sentença a aptidão para revestir-se da auctoritas rei iudicatae no sentido material..$^{29}$ É essa autoridade, e não qualquer aliud, que impedirá o órgão judicial, noutro eventual processo, de rejulgar a lide.

Diferentemente se passam as coisas quando a sentença puser termo ao feito sem apreciação do mérito. Por exemplo: o habeas data foi impetrado por pessoa diversa daquela a quem dizem respeito as informaçōes a que se pretende ter acesso. Falece ao impetrante legitimação ativa para a causa (cf., supra, $\mathrm{n}^{2} 9$ ). $O$ caso é de extinção do processo sem julgamento de meritis, e não haverá coisa julgada material. A disciplina da matéria não discrepa, em suma, da consagrada no Código de Processo Civil.

15. Competência: A) originária - Está regulada, em grande parte, na própria Constituição a competência para conhecer de habeas data e julgá-lo. No grau inferior de jurisdição, ela se reparte entre a Justiça federal e a Justiça dos Estados. São competentes os juízes federais para os habeas data impetrados contra autoridade federal, excetuados os casos de competência originária de tribunais federais (art. 109, n⿳⺈ VIII). Os juízes estaduais têm competência residual: exercem-na quando não haja disposição que a atribua ou aos juízes federais ou, originariamente, a algum tribunal.

A competência originária pertence: a cada um dos Tribunais Regionais Federais, para os habeas data contra o próprio tribunal ou órgão inferior da Justiça federal

28 Vide referências em THEOTONIO NEGRĀO, Código de Processo Civil e legislaçāo processual em vigor, $28^{\mathrm{a}}$ ed., S. Paulo, 1997, p. 1.139, nota 1 ao art. 16 da Lei $\mathbf{n}^{\mathrm{N}} 1.533$.

29 Pouco persuasiva a argumentação (antes da Lei ne 9.507) de CALMON DE PASSOS, ob. cit., p. 154, - qual parece levar em conta apenas a hipótese de concessāo da ordem. Escreve esse autor: "Renovado um pedido de habeas data a respeito da mesma pessoa e em relação ao mesmo sujeito passivo, o que há e opera com força obstativa do bis in idem não é a coisa julgada, sim o adimplemento, como a prova do pagamento extinge a execução que se renove com base no mesmo título executivo". Deixando de lado outros aspectos da questão, objetaríamos que, no exemplo figurado em nosso texto, não há cogitar de adimplemento. Tanto basta para infirmar o asserto, feito sic et simpliciter, de que c " inadequado falar-se em coisa julgada material no habeas data". 
(art. 108, $\mathrm{n}^{2} \mathrm{I}$, letra c); ao Superior Tribunal de Justiça, para os habeas data contra Ministro de Estado ou o próprio tribunal (art. 105, ne I, letra $b$ ): ao Supremo Tribunal Federal, para os habeas data contra o Presidente da República, a Mesa da Câmara dos Deputados ou do Senado Federal, o Tribunal de Contas da União, o Procurador-Geral da República ou o próprio tribunal (art. 102, $\mathrm{n}^{\mathfrak{Q}} \mathrm{I}$, letra $d$ ).

Todas essas regras foram reproduzidas no art. 20, $\mathrm{n}^{\circ} \mathrm{I}$, letras $a, b, c, d, f$, da Lei $\mathrm{n}^{2}$ 9.507. A letra $e$ trata de hipótese não contemplada expressis verbis na Carta Política da União: a da competência originária de tribunal estadual. Na conformidade da cláusula final, a matéria ficará sujeita ao "disposto na Constituição do Estado" - o que se harmoniza com a norma do art. $125, \S 1^{2}$, da Constituição federal: "A competência dos tribunais [estaduais] será definida na Constituição do Estado, sendo a lei de organização judiciária da iniciativa do Tribunal de Justiça".

16. Competência: B) recursal - Também se encontram na Carta da União regras sobre a competência para conhecer de recurso interposto contra decisão em habeas data. Se ela emanar de juiz federal, competente para julgar a apelação será o Tribunal Regional Federal (art. 108, $n^{\mathcal{e}}$ II, onde a palavra "causas" abrange, à evidência, a de que estamos cuidando, objeto de menção específica, quanto ao primeiro grau, no art. $109, n^{0}$ VIII); a Lei $n^{2} 9.507$ repete a disposição no art. $20, n^{2}$ II, letra $c$. Sendo a decisão proferida em única instância por qualquer dos tribunais superiores, e denegatória ${ }^{30}$ o recurso cabível é o ordinário, e a competência recursal é do Supremo Tribunal Federal (art. 102, $\mathrm{n}^{\mathrm{Q}}$ II, $a$, reproduzido no art. 20, $\mathrm{n}^{\mathbb{2}}$ II, letra a, da Lei ne 9.507). Pode ainda caber a competência recursal aos tribunais estaduais e ao do Distrito Federal e Territórios, "conforme dispuserem a respectiva Constituição e a lei que organizar a Justiça do Distrito Federal" (Lei n 9.507, art. 20, ne II, letra $d$ ).

Falta aludir a um caso peculiar. Na enumeração das hipóteses de competência recursal do Superior Tribunal de Justiça (art. 105, ns II e III), a Constituição da República nada contém de específico acerca do habeas data. No que toca a recursos contra decisões proferidas pelos Tribunais Regionais Federais, há apenas duas referências: $a$ do $n^{2}$ II. Letra $b$, atinente ao recurso ordinário em "mandados de segurança decididos em única instância" por esses tribunais, "quando denegatória a decisão"; e a do $n^{2}$ III, concernente ao recurso especial cabível, em determinadas hipóteses, nas "causas decididas, em única ou última instância", pelos mesmos Tribunais Regionais Federais (em ambos os textos se faz menção a outros tribunais, que aqui não interessam). No entanto, lê-se no art. $20, \mathrm{n}^{2}$ II, letra $b$, da Lei $n^{2} 9.507$, que o julgamento do habeas data compete, em grau de recurso, ao Superior Tribunal de

$30 \mathrm{Na}$ interpretaçāo do art. 102, $\mathrm{n}^{2}$ II, letra $a$, e 105, n² II, letra $b$, da Carta da República, que usam o adjetivo com relação a decisões em mandado de segurança, os tribunais têm atribuído à expressão sentido Lurgo, a compreender não só as decisōes desfavoráveis de meritis ao impetrante, mas também as que emtingue o processo do mandado de segurança sem apreciação do mérito: vide as referências jurisprudencies en THEOTONIO NEGRĀO, ob. cit., p. 436, nota 8 no art. 539 do Código de Processo Civil, e p. 1.229, sota 3 wo a. 247 do Regimento Interno do Superior Tribunal de Justiça. Tudo faz crer que igual entendimento prevaleceŕ́ em matéria de habeas data. 
Justiça, "quando a decisão for proferida em única instância pelos Tribunais Regionais Federais".

O dispositivo gera problema hermenêutico de difícil solução. Não se sabe se pretendeu somente - à semelhança de vários outros do art. 20 - reiterar previsão constitucional, ou se visou a abrir via recursal não contemplada na Lei Maior. Neste último caso, expõe-se à argüição de inconstitucionalidade, desde que se adote a premissa de que a competência do Superior Tribunal de Justiça se acha exaustivamente definida na Constituição e não pode ser ampliada por lei ordinária. ${ }^{31}$ No primeiro, a única possibilidade consiste em entendê-lo como referente ao recurso especial: mas os pressupostos de cabimento, tais como enunciados na Lei $n^{2}$ 9.507, não coincidem com os constitucionalmente estabelecidos.

Com efeito. De um lado, o recurso especial, segundo a Constituição (art. 105, n III), não cabe apenas contra decisões proferidas em "única instância" por Tribunal Regional Federal, senão também contra decisões por qualquer deles proferidas "em última instância"; de outro lado, para que caiba o recurso especial, sempre de acordo com o art. 105, ne III, da Constituição, é imprescindível que se configure alguma das hipóteses catalogadas nas letras $a, b$ e $c$, a saber: que a decisão impugnada contrarie tratado ou lei federal; julgue válida lei ou ato de governo local contestado em face de lei federal: ou dê a lei federal interpretação divergente da que the haja atribuído outro tribunal. Ora, ao propósito é de todo em todo silente o art. 20, $n^{2}$ II, letra $b$, da Lei $\mathrm{n}^{\mathbf{2}}$ 9.507. Resta verificar como desatará a jurisprudência o nó dado pelo legislador.

Para terminar, anote-se que o $n^{2}$ III do mesmo art. 20 faz alusão ao "recurso extraordinário ao Supremo Tribunal Federal", cabível em matéria de habeas data (como em qualquer outra!) "nos casos previstos na Constituição", isto é: nas causas decididas em única ou última instância, quando a decisão recorrida contrariar dispositivo da própria Constituição, declarar a inconstitucionalidade de tratado ou lei federal ou julgar válida lei ou ato de governo local contestado em face da Constituição (art. 103, n III, letras $a, b$ e $c$, respectivamente).

31 Nesse sentido, por exemplo, JOSÉ CRETELLA JÚNIOR, ob. cit., vol. VI, Rio de Janeiro, 1992, p. 3.119: "A Constituiçāo vigente explicita de modo exaustivo a competência do Superior Tribunal de Justiça, no que diz respeito ao processamento e julgamento de causas, quer em caráter originário, quer em via recursal" (sem grifo no original). 


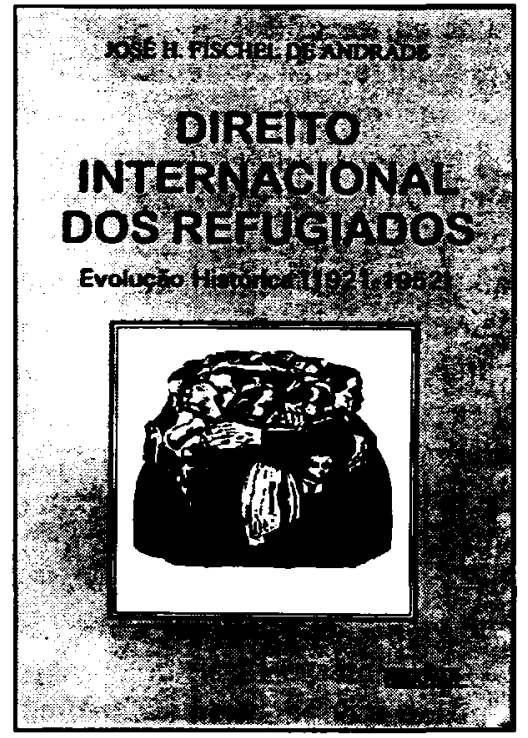

Ref. 0103

Brochura

228 págs.

Form. 14x21

1996

\section{DIREITO INTERNACIONAL DOS REFUGIADOS}

José H. Fischel de Andrade

O presente livro trata da fase histórica do Direito Internacional dos Refugiados, a qual se estende de 1921 a 1952. O Autor contextualiza o momento histórico, abordando a agenda internacional, a evolução das relaçōes internacionais, e os fatores políticos, sociais e jurídicos que influenciaram as decisões tomadas em nivel intergovernamental e que repercutiram na proteçāo brindada aos perseguidos. Neste sentido, são minuciosamente estudados tanto os diversos instrumentos jurídicos concertados, com suas distintas definições do que se deveria entender por "refugiado", quanto as várias organizaçōes internacionais criadas com vistas à proteção dos refugiados pela comunidade internacional. 